\title{
A NEW IRANIAN SPECIES OF UROLEUCON MORDVILKO, 1914 (HEMIPTERA, APHIDIDAE) FROM SPECIMENS IN THE NATURAL HISTORY MUSEUM COLLECTION
}

\author{
Juan M. Nieto Nafría* \& Nicolás Pérez Hidalgo** \\ *** Departamento de Biodiversidad y Gestión Ambiental; Universidad de León. 24071 León (Spain). e-mail 1: jmnien@unileon.es. \\ urn:Isid:zoobank.org:author:81F0702F-538F-4AB4-92A9-74580A562221 \\ ** e-mail 2: nperh@unileon.es. urn:Isid:zoobank.org:author:C134E648-51C1-48A2-8676-2E9517657FAE
}

\section{ABSTRACT}

Uroleucon (Uromelan) helichrysi sp. n. (Hemiptera, Aphididae, Aphidinae: Macrosiphini) is established from Iranian apterous and alate viviparous females caught on Helichrysum sp. (Asteraceae) and preserved in the collection of the Natural History Museum (BMNH) in London. The number of setae on the first tarsal segments (5), the number of caudal setae (20 to 28), the presence of abdominal marginal tubercles on abdominal segments 2 to 4 , and the size of the cells of the siphuncular reticulation (relatively small) allow the new species to be distinguished from other Palaeartic species of the subgenus Uromelan. Blackman and Eastop's key to apterae on Helichrysum is modified to include the new species.

urn:Isid:zoobank.org:pub:E2B89D59-05FD-4A9E-AD78-B3С302219A10

Key words: Aphids; Macrosiphini; Iran; Helichrysum; Asteraceae.

\section{RESUMEN}

Nueva especie iraní de Uroleucon Mordvilko, 1914 (Hemiptera, Aphididae) descrita a partir de ejemplares de la colección del Natural History Museum

Se establece la especie Uroleucon helichrysi n. sp. (Hemiptera: Aphididae: Aphidinae: Macrosiphini) con la descripción de sus hembras vivíparas ápteras y aladas recogidas en Irán sobre Helichrysum sp. (Asteraceae), conservadas en la colección del Natural History Museum de Londres. La nueva especie se diferencia de otras especies paleárticas del subgénero Uromelan por la cantidad de setas en el primer segmento tarsal (5), la cantidad de setas caudales (20 a 28), por el tamaño de las celdillas de la reticulación cornicular (que son relativamente pequeñas) y por la presencia de papilas marginales (presentes en los segmentos abdominales 2 a 4) Se incluye una modificación a la clave de Blackman and Eastop para las ápteras que viven sobre Helichrysum.

Palabras clave: Pulgones; Áfidos; Macrosiphini; Irán; Helichrysum; Asteraceae.

Recibido/Received: 17/09/2013; Aceptado/Accepted: 25/02/2014; Publicado en línea/Published online: 22/08/2014

Como citar este artículo/Citation: Nieto Nafría, J. M. \& Pérez Hidalgo, N., 2014. A new iranian species of Uroleucon Mordvilko, 1914 (Hemiptera, Aphididae) from specimens in the Natural History Museum collection. Grael/sia, 70(1): e004. http://dx.doi.org/10.3989/graellsia.2014.v70.104.

Copyright: (C) 2014 SAM y CSIC. Salvo indicación contraria, todos los contenidos de la edición electrónica de Grael/sia se distribuyen bajo licencia de uso y distribución Creative Commons Reconocimiento no Comercial 3.0. España (cc-by-nc). 


\section{Introduction}

It is well established that an significant part of the biodiversity is as yet undescribed, but it is not well known that an important portion of new species established by professional or non-professional (amateur) taxonomists is based on specimens preserved in the collections of museums, universities and other scientific institutions (Winston, 1999; Fontaine et al., 2012). Such collections also include many species that are still undescribed (Blackman \& Eastop, 2006).

Specimens of two samples in the aphid collection of the Natural History Museum in London (BMNH) belonging to genus Uroleucon Mordvilko, 1914 (Hem. Aphididae Aphidinae Macrosiphini) have been studied, one from Lebanon and another from Iran. The slides of both samples had been labelled as new species by D. Hille Ris Lambers, and one of them is mentioned by Blackman \& Eastop (2006, page 229).

Uroleucon currently includes 235 valid species and several subspecies (Favret, 2013; Nieto Nafría \& Pérez Hidalgo, 2013), being one the largest genera of the tribe Macrosiphini.

\section{Material and methods}

The studied samples do not have a distinctive number; one is from Lebanon and the other from Iran.

Lebanese sample: "Carthamus flavescens, Arec, 26-XI-1971, Talhouk leg. (nr. 39)";14 apterous viviparous females, 4 alate viviparous females and 6 immature specimens. This sample is mentioned by Blackman \& Eastop (2006 [2013], page 229) as Uroleucon sp. near jaceae. The locality of Arec is in the Bekaa valley.

Iranian sample: "Helichrysum sp., Demavend Village, 12-VI-1960, van den Bosch leg. (IR 132)"; 25 apterous viviparous females, 5 alate viviparous females and 22 immature specimens. This sample is not mentioned by Blackman and Eastop (op. cit.). We think that the locality "Demavend" is a misspelling for Damavand, a locality near Mount Damavand.

Measurements of the slide-mounted specimens were made according to Nieto Nafría \& Mier Durante (1998) with an ocular micrometer. The measurements are lengths except when indicated that they are a width or diameter.

The photomicrographs were taken with a Leica DC digital camera with IM 1000 version 1.10 software.

\section{Results and Discussion}

The Lebanese specimens above mentioned have been identified as Uroleucon jaceae (Linnaeus, 1758). We do not put a subspecific name on these specimens, because the species is very variable and the subspecies are badly defined.

The specimens of the Iranian sample are different to the Lebanese specimens, mainly in the shape and ornamentation of the siphunculi. We consider that these aphids belong to a new species of the genus Uroleucon, subgenus Uromelan.

\section{Uroleucon helichrysi sp. $\mathrm{n}$.}

urn:1sid:zoobank.org:act:20A34165-03B9-425A-8B8EF4E7A8DCEF5D

TYPES. Holotype: Apterous viviparous female, number 3 of the measurement series, IRAN, Mazanderan province, Damavand, 12-VI-1960, on Helichrysum sp., v.d.Bosch leg. (IR 132). Paratypes: 24 apterous viviparous females and 5 alate viviparous females, same data. Collection of the Natural History Museum (BMNH), London, United Kingdom.

Apterous viviparous females (Table 1, Fig. 1). From 39 apterous viviparous females. Metric and meristic features in Table 1. Colour in life unknown. When mounted mostly pale yellowish brown with striae on dorsum of thorax and abdomen. Marginal tubercles usually present in prothorax and abdominal segments 2-4; they are small, similar in size to neighbouring seta sockets. Setae thick and pale, most of them with blunt or evanescent apex. Head brown, and dorsally with very faint striae. Frontal sinus very deep and fronto-medial tubercle small or inconspicuous (Fig. 1A). Antennae brown to dark brown, usually with the proximal portion of segment III paler; proximal portion of segment III and most of IV delicately ornamented, segments V and VI imbricated. Secondary sensoria scattered on proximal $50-66 \%$ of segment III; they are circular, small and somewhat protuberant. Rostrum reaching hind coxae, dark brown; ultimate rostral segment triangular; proximal ones with spinules. Thorax with striate pale brown marginal sclerites in addition to the brown spinal and pleural setiferous scleroites. Coxae, distal 1/3-1/2 of femora, very proximal portion and distal $2 / 5-1 / 3$ of tibiae, and tarsi dark brown. Abdomen with dorsal setiferous scleroites (Fig. 1B), with neighbouring scleroites on abdominal segment 7 and 8 sometimes coalescent; postsiphuncular and antesiphuncular (sometimes broken) patches; and spiracular sclerites small and usually paler than the setiferous scleroites; the intersegmental sclerites are inconspicuous. Siphunculi dark brown (Fig. 1C), cylindrical with enlarged base and curved outward, and without both preapical incision and flange; cells of the reticulate part very small (Fig. 1E); part proximal to reticulation densely covered with groups of spinules or scales. Genital plate light brown with brown spots. Anal plate similar in colour to cauda, which is lanceolate and as dark as siphunculi (Fig. 1D). 
Table 1.- Metric and meristic features of apterous and alate viviparous females of Uroleucon helichrysi sp. $\mathbf{n}$.

Tabla 1.- Características métricas y merísticas de las hembras vivíparas ápteras y aladas de Uroleucon helichrysi n. sp.

\begin{tabular}{|c|c|c|}
\hline & apterous viviparae & alate viviparae \\
\hline Body (cauda included) (mm) & $3.775-4.625$ & $3.550-4.500$ \\
\hline Antenna (mm) & $3.810-3.990$ & $3.410-4.520$ \\
\hline Antennal segment III [Ant.III] (mm) & $0.98-1.08$ & $0.88-1.12$ \\
\hline Antennal segment IV (mm) & $0.72-0.85$ & $0.64-0.92$ \\
\hline Antennal segment V (mm) & $0.60-0.72$ & $0.56-0.80$ \\
\hline Antennal segment VI, base [Ant.VI base] (mm) & $0.16-0.19$ & $0.16-0.21$ \\
\hline Antennal segment VI, terminal processus [Ant.Vl.t.p.] (mm) & $0.85-1.03$ & $0.90-1.23$ \\
\hline Ultimate rostral segment [U.r.s.] (mm) & $0.19-0.21$ & $0.19-0.21$ \\
\hline Hind Femur [H.F.] (mm) & $1.40-1.50$ & $1.08-1.48$ \\
\hline Hind Tibia [H.T.] (mm) & $2.43-2.55$ & $2.03-2.70$ \\
\hline Second segment of hind tarsi [H.t.2] (mm) & $0.15-0.17$ & $0.13-0.16$ \\
\hline Siphunculus [SIPH.] (mm) & $1.00-1.13$ & $0.82-1.18$ \\
\hline Cauda (mm) & $0.60-0.70$ & $0.46-0.58$ \\
\hline Body / H.F. (times) & $2.60-3.25$ & $2.91-3.30$ \\
\hline Body / H.T. (times) & $1.55-1.89$ & $1.60-1.75$ \\
\hline Antenna / Body (times) & $0.87-1.00$ & $0.96-1.11$ \\
\hline Ant.III / Ant.VI base & $5.44-6.31$ & $5.33-5.94$ \\
\hline Ant.III / U.r.s. & 4.67-5.35 & $4.51-5.63$ \\
\hline Ant.VI.t.p. / Ant.III (times) & $0.81-1.01$ & $1.02-1.12$ \\
\hline Ant.VI.t.p. / Ant.VI base (times) & $4.58-6.00$ & $5.63-6.15$ \\
\hline U.r.s. / basal width of U.r.s. (times) & $2.67-3.15$ & 2.79 \\
\hline U.r.s. / Antennal segment I (times) & $0.87-1.05$ & $0.95-1.08$ \\
\hline U.r.s. / Ant.VI base (times) & $1.08-1.31$ & $0.98-1.22$ \\
\hline U.r.s. / interocular dorsal distance (times) & $0.43-0.53$ & $0.46-0.49$ \\
\hline U.r.s. / H.t.2 (times) & $1.15-1.26$ & $1.31-1.50$ \\
\hline SIPH. / Body (times) & $0.22-0.28$ & $0.23-0.28$ \\
\hline SIPH. / Ant.III (times) & $0.93-1.12$ & $0.93-1.17$ \\
\hline SIPH. / interocular dorsal distance (times) & $2.15-2.68$ & $2.20-2.61$ \\
\hline SIPH. / basal width of SIPH. (times) & $3.89-4.74$ & $4.56-5.62$ \\
\hline SIPH. / minimal width of SIPH. (times) & $7.14-9.64$ & $6.83-12.42$ \\
\hline Basal / minimal widths of SIPH. (times) & $1.64-2.18$ & $1.50-2.35$ \\
\hline Basal width of SIPH. / diameter of Hind tibia at its middle (times) & $1.22-2.00$ & $1.46-2.00$ \\
\hline Reticulated portion of SIPH. / SIPH. (times) & $0.18-0.27$ & $0.21-0.25$ \\
\hline Cauda / SIPH. (times) & $0.58-0.69$ & $0.47-0.56$ \\
\hline Cauda / basal width of Cauda (times) & $2.36-2.65$ & $1.96-2.33$ \\
\hline Secondary sensoria on Ant.III (number) & $31-52$ & $60-82$ \\
\hline Setae on U.r.s. (number) & $7-10$ & $6-8$ \\
\hline Setae on abdominal segment $3^{\text {rd }}$, dorsum (number) & $18-27$ & $23-34$ \\
\hline Setae on abdominal segment $7^{\text {th }}$, dorsum (number) & $6-11$ & $8-12$ \\
\hline Setae on abdominal segment $8^{\text {th }}$ (number) & $4-6$ & $4-6$ \\
\hline Setae on cauda (number) & $20-28$ & $21-25$ \\
\hline Setae on subgenital plate, discal (number) & $4-8$ & $5-12$ \\
\hline Setae on subgenital plate, marginal (number) & $18-23$ & $16-18$ \\
\hline Rows on reticulate portion of siphunculi & $20-25$ & $11-18$ \\
\hline
\end{tabular}


Table 1 (continued)

\begin{tabular}{|c|c|c|}
\hline & apterous viviparae & alate viviparae \\
\hline \multicolumn{3}{|l|}{ Longest seta on ... } \\
\hline ... Antennal segment III $(\mu \mathrm{m})$ & $38-50$ & $28-45$ \\
\hline ... Antennal segment III / basal width of Ant.III (times) & $0.6-0.8$ & $0.5-0.9$ \\
\hline$\ldots$ Vertex $(\mu \mathrm{m})$ & $55-75$ & $50-60$ \\
\hline ... Vertex / basal width of Ant.III (times) & $0.8-1.2$ & $0.9-1.1$ \\
\hline$\ldots$ Hind trochanter, posterior $(\mu \mathrm{m})$ & $50-75$ & $45-50$ \\
\hline ... Hind trochanter, posterior / (/) tr. (times) & $0.5-0.7$ & $0.5-0.6$ \\
\hline$\ldots$ H.F., dorsum $(\mu \mathrm{m})$ & $40-55$ & $30-40$ \\
\hline$\ldots$ H.F., venter $(\mu \mathrm{m})$ & $45-100$ & $40-60$ \\
\hline ... H.F., dorsum / basal width of Ant.Ill (times) & $0.6-0.8$ & $0.6-07$ \\
\hline ... H.F., venter / basal width of Ant.III (times) & $0.8-1.5$ & $0.7-1.2$ \\
\hline$\ldots$ H.T., dorsum at middle $(\mu \mathrm{m})$ & $50-60$ & $35-45$ \\
\hline ... H.T., dorsum / diameter of H.T at middle & $0.5-0.8$ & $0.6-0.7$ \\
\hline$\ldots$ abdominal segment $3^{\text {rd }}$, spinal or pleural $(\mu \mathrm{m})$ & $38-80$ & $48-55$ \\
\hline ... abdominal segment $3^{\text {rd }} /$ basal width of Ant.III (times) & $0.6-1.3$ & $0.8-1.1$ \\
\hline$\ldots$ abdominal segment $8^{\text {th }}(\mu \mathrm{m})$ & $60-83$ & $60-80$ \\
\hline$\ldots$ abdominal segment $8^{\text {th }} /$ basal width of Ant.III (times) & $0.9-1.3$ & $1.1-1.6$ \\
\hline
\end{tabular}

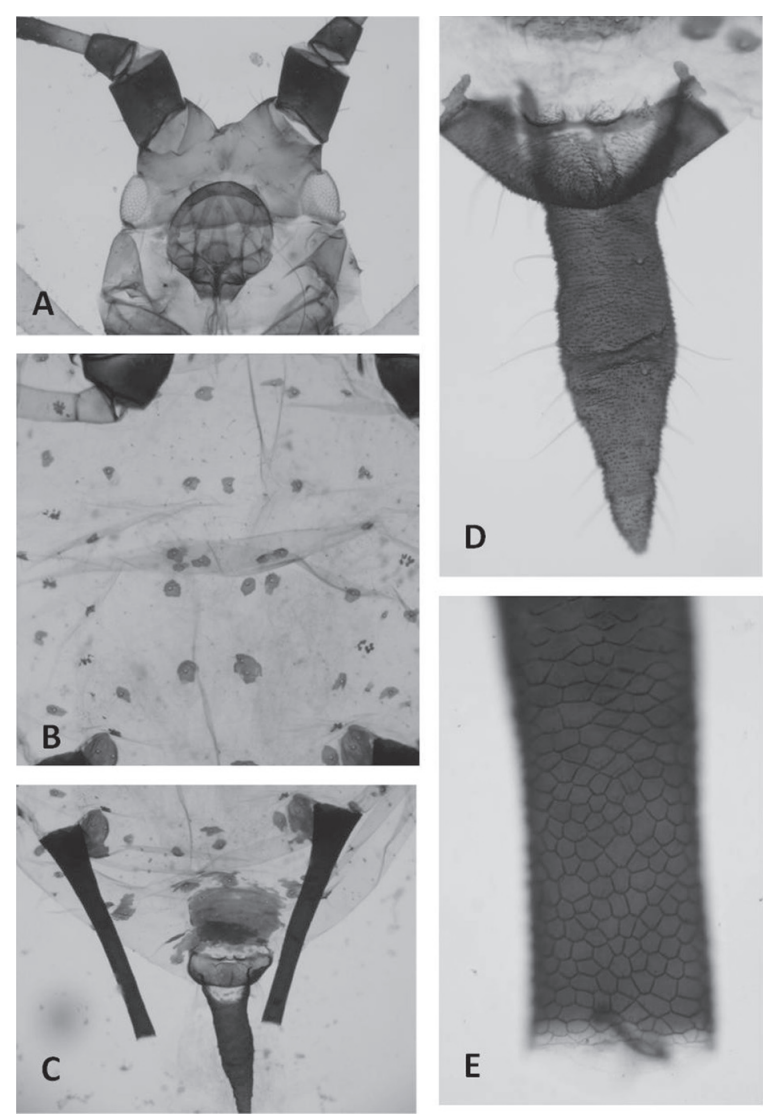

Fig. 1.- Apterous viviparous females: Uroleucon (Uromelan) helichrysi sp. n.: head (A), anterior abdominal segments (B), posterior abdominal segments (C), cauda (D), and apical part of siphunculi (F).

Fig. 1.- Hembras vivíparas ápteras: Uroleucon (Uromelan) helichrysi sp. n.: cabeza $(A)$, segmentos anteriores del abdomen (B), parte posterior del abdomen (C), cola (D) y parte apical del cornículo (F).
Alate viviparous females (Table 1, Fig. 2). From 9 alate viviparous females. Metric and meristic features in Table 1. Colour in life unknown; when mounted similar to apterae (Figs. 2A, 2B). Antennae brown to dark brown, usually with the proximal portion of segment III paler (Fig. 2C). Secondary sensoria (60-82) circular small and somewhat protuberant (Figs. 2C, 2D). Abdomen with dorsal setiferous sclerites (Fig. 2B). Siphunculi dark brown (Fig. 2B), similar to those of the apterae, without both preapical incision and flange. Cauda is lanceolate and as dark as siphunculi.

BionOMics. The only known host plant of the aphid is an unidentified species of Helichrysum (Asteraceae); the capacity of this aphid to colonize other composites is unknown.

Distribution. The new species is only known from one Iranian locality, in Mazanderan province.

Etymology. The specific name helichrysi is the genitive of the name of the host plant of the new aphid species.

TAXONOMIC DISCUSSION. The assignment of the species to genus Uroleucon and subgenus Uromelan Mordvilko, 1914 is unquestionable, given the characteristics described above.

The principal characters involved in the comparison of $U$. helichrysi sp. n. (this work) to other Palaearctic species of Uromelan (original descriptions) are the tarsal formula (5.5.5), the number of caudal setae (20-28), the size of the siphuncular cells 

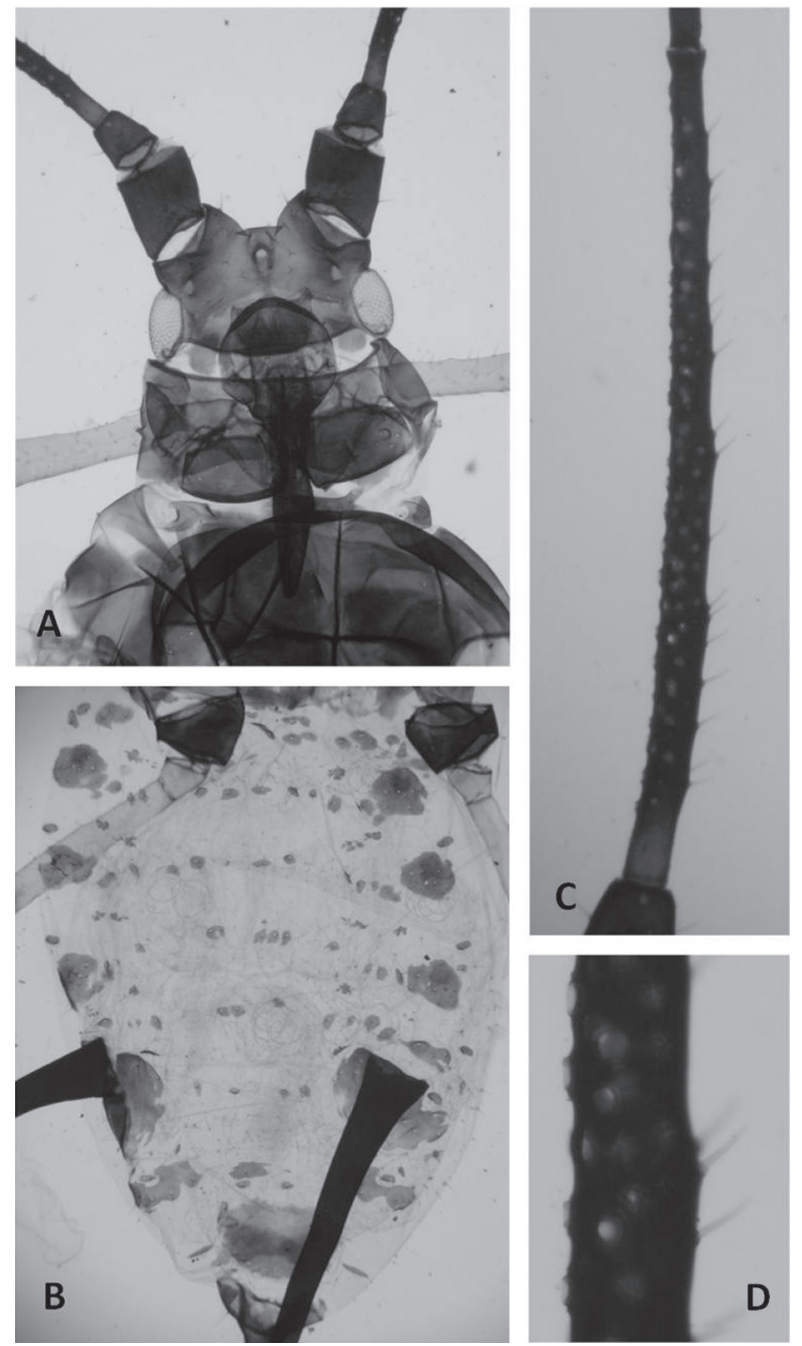

Fig. 2.- Alate viviparous females: Uroleucon (Uromelan) helichrysi sp. n.: head and thorax (A), abdominal segments (B), antennal segment III (C), and detail of secondary sensorial of antennal segment III (D).

Fig. 2.- Hembras vivíparas aladas: Uroleucon (Uromelan) helichrysi sp. n.: cabeza y parte del tórax (A), abdomen (B), antenómero III (C) y detalle de los sensorios secundarios del antenómero III (D).

and the presence of marginal tubercles on abdominal segments 2-4.

Most Palaearctic Uromelan species have 5 setae on the first tarsal segments, but only five of them have 20 or more caudal setae (Hille Ris Lambers, 1939; Miyazaki, 1971; Takahashi, 1962; Rezwani \& Lampel, 1987; Heie, 1995; Lee et al., 2002): U. aeneum (Hille Ris Lambers, 1939), U. caspicum Rezwani \& Lampel, 1987; U. cephalonopli (Takahashi, 1962), U. giganteum (Matsumura, 1918) and U. jaceae (Linnaeus, 1758).

U. caspicum and U. giganteum (Matsumura, 1918) have many more setae on the cauda than $U$. helichrysi (24-41 and 40-60 respectively). U. cephalonopli has, in comparison with $U$. helichrysi, a long and narrow ultimate rostral segment $(0.22-0.30 \mathrm{~mm}$ and 1.4-1.6 times second segment of hind tarsus), and the siphunculi and cauda are different in shape (see Lee et al., 2002, fig. 227). U. jaceae lacks abdominal marginal tubercles, and the cells of the siphuncular reticulation are larger than those in $U$. helichrysi, as in U. aeneum. The metric and meristic characteristics of $U$. aeneum are very similar to those of the new species, but the shape and reticulation of the siphunculi are very different. In addition none of these species live on Helichrysum.

The "Key to apterae on Helichrysum" by Blackman \& Eastop (2006, p. 510) can be modified to include U. helichrysi sp. n. as follows, respecting terminology, abbreviations and expressions.

15. [without modifications]........ Uroleucon cichorii

- SIPH 1.5-2.1× cauda, which is dark Antesiphuncular sclerites absent .................15B

16B. SIPH 1.8-2.1× cauda, which has 11-20 hairs Uroleucon compositae (or gobonis) SIPH 1.5-1.7× cauda, which has 20-28 hairs........ Uroleucon helichrysi

\section{Acknowledgments}

The authors wish to thank the Natural History Museum of London for the facilities to study the slides of its collection.

\section{References}

Blackman, R. L. \& Eastop, V. F., 2006. Aphids on the World's herbaceous plants and shrubs. Volume 1 Host Lists. Volume 2 The Aphids. John Wiley \& Sons, Ltd. Chicheter (U. K.). 8+1024 pp. Actualized 2013: Aphids on the World's plants. An online identification and informative guide. Web service available online at http://www.aphidsonworldsplants.info [consulted April 2013].

Favret, C., 2013. Aphid Species File. Version 1.0/4.1. [Consulted April 2013]. <http://Aphid.SpeciesFile.org>.

Fontaine, B., van Achterberg, K., Alonso-Zarazaga, M. A. Araujo, R., Asche, M., Aspöck, H., Aspöck, U., Audisio, P., Aukema, B., Bailly, N., Balsamo, M., Bank, R. A., Belfiore, C., Bogdanowicz, W., Boxshall, G., Burckhardt, D., Chylarecki, P., Deharveng, L., Dubois, A., Enghoff, H., Fochetti, R., Fontaine, C., Gargominy, O., Gómez López, M. S., Goujet, D., Harvey, M. S., Heller, K. G., van Helsdingen, P., Hoch, H., De Jong, Y., Karsholt, O., Los, W., Magowski, W., Massard, J. A., McInnes, S. J., Mendes, L. F., Mey, E., Michelsen, V., Minelli, A., Nieto Nafría, J. M., van Nieukerken, E. J., Pape, T., De Prins, W., Ramos, M., Ricci, C., Roselaar, C., Rota, E., Segers, H., Timm, T., van Tol, J., Bouchet, P., 2012. New Species in the Old World: Europe as a Frontier in Biodiversity Exploration, a Test Bed for 21st Century Taxonomy. PLoS ONE, 7(5): e36881, 7 pp. http://dx.doi.org/doi:10.1371/journal.pone.0036881.

Heie, O. E., 1995. The Aphidoidea (Hemiptera) of Fennoscandia and Denmark. VI. Family Aphididae: Part 3 of tribe Macrosiphini of subfamily Aphidinae, and family Lachnidae. Fauna Entomologica Scandinavica, 31: 1-217. 
Hille Ris Lambers, D., 1939. Contributions to a monograph of the Aphididae of Europe. II. The genera Dactynotus Rafinesque, 1818; Staticobium Mordvilko, 1914; Macrosiphum Passerini, 1860; Masonaphis nov. gen.; Pharalis Leach, 1826. Temminckia, 4: 1-134 \& 6 plates.

Lee, S. H., Holman, J. \& Havelka, J., 2002. Illustrated catalogue of Aphididae in the Korean Peninsula. Part I, Subfamily Aphidinae (Hemiptera Sternorryncha). In: K.-T. Park (ed.). Insects of Korea [9]. Korea Research Institute of Bioscience \& Biotechnology and the Center for Insects Systematics. [Without locality]. $331 \mathrm{pp}$.

Miyazaki, M., 1971. A revision of the tribe Macrosiphini of Japan (Homoptera: Aphididae, Aphidinae). Insecta Matsumurana, 34(1): 1-247.

Nieto Nafría, J. M. \& Mier Durante, M. P., 1998. Hemiptera Aphididae I. In: M. A. Ramos et al. (eds.). Fauna
Ibérica, volumen 11. Museo Nacional de Ciencias Naturales (CSIC). Madrid. 424 pp.

Nieto Nafría, J. M. \& Pérez Hidalgo, N., 2013. Two new Palaearctic species of Uroleucon (Hemiptera: Aphididae) from the collection of the Muséum national d'Histoire naturelle de Paris. Boletín de la Asociación Española de Entomología, 37(1-2): 31-47.

Rezwani, A. \& Lampel, G., 1987. Two new species of Uroleucon Mordv. (Homoptera: Aphididae) from Iran. Mitteilungen der Schweizerischen Entomologischen Gesellschaft, 60: 325-330.

Takahashi, R., 1962. Key to Japanese species of Dactynotus, with descriptions of four new species (Aphididae, Homoptera). Kontyû, 30(2): 73-81.

Winston, J. E., 1999. Describing Species, Practical Taxonomic Procedure for Biologists. Columbia University Press. New York. 541 pp. 